\title{
Pharmacological Agents Targeting the Cellular Prion Protein
}

\author{
Maria Letizia Barreca ${ }^{1, *}$, Nunzio Iraci ${ }^{1}$ (i), Silvia Biggi ${ }^{2}$, Violetta Cecchetti ${ }^{1}$ and \\ Emiliano Biasini $2,3, *$ \\ 1 Department of Pharmaceutical Sciences, University of Perugia, 06123 Perugia, Italy; \\ nunzio.iraci@gmail.com (N.I.); violetta.cecchetti@unipg.it (V.C.) \\ 2 Dulbecco Telethon Laboratory of Prions and Amyloids, Centre for Integrative Biology (CIBIO), \\ University of Trento, 38123 Trento, Italy; silvia.biggi@unitn.it \\ 3 Department of Neuroscience, IRCCS-Istituto di Ricerche Farmacologiche Mario Negri, 20156 Milan, Italy \\ * Correspondence: maria.barreca@unipg.it (M.L.B.); emiliano.biasini@unitn.it (E.B.)
}

Received: 8 February 2018; Accepted: 2 March 2018; Published: 7 March 2018

\begin{abstract}
Prion diseases are associated with the conversion of the cellular prion protein $\left(\mathrm{PrP}^{\mathrm{C}}\right)$, a glycoprotein expressed at the surface of a wide variety of cell types, into a misfolded conformer (the scrapie form of $\mathrm{PrP}$, or $\mathrm{PrP}^{\mathrm{Sc}}$ ) that accumulates in brain tissues of affected individuals. $\mathrm{PrP}^{\mathrm{Sc}}$ is a self-catalytic protein assembly capable of recruiting native conformers of $\operatorname{PrP}^{\mathrm{C}}$, and causing their rearrangement into new $\mathrm{PrP}^{\mathrm{Sc}}$ molecules. Several previous attempts to identify therapeutic agents against prion diseases have targeted $\mathrm{PrPS}^{\mathrm{Sc}}$, and a number of compounds have shown potent anti-prion effects in experimental models. Unfortunately, so far, none of these molecules has successfully been translated into effective therapies for prion diseases. Moreover, mounting evidence suggests that $\mathrm{PrP}^{\mathrm{Sc}}$ might be a difficult pharmacological target because of its poorly defined structure, heterogeneous composition, and ability to generate different structural conformers (known as prion strains) that can elude pharmacological intervention. In the last decade, a less intuitive strategy to overcome all these problems has emerged: targeting $\operatorname{PrP}^{\mathrm{C}}$, the common substrate of any prion strain replication. This alternative approach possesses several technical and theoretical advantages, including the possibility of providing therapeutic effects also for other neurodegenerative disorders, based on recent observations indicating a role for $\mathrm{PrP}^{\mathrm{C}}$ in delivering neurotoxic signals of different misfolded proteins. Here, we provide an overview of compounds claimed to exert anti-prion effects by directly binding to $\mathrm{PrPC}$, discussing pharmacological properties and therapeutic potentials of each chemical class.
\end{abstract}

Keywords: cellular prion protein; prion diseases; PrP ligands; pharmacological chaperones

\section{Introduction}

With few exceptions, proteins evolved their biological function in parallel with the ability to remain soluble under physiological conditions. However, in several pathological situations, specific proteins lose their native fold and acquire a different tertiary and quaternary conformation, clustering into aberrant aggregates. This phenomenon, known as protein misfolding, lays at the root of a wide variety of human diseases, such as neurodegenerative disorders, in which protein aggregation occurs in the brain [1]. Examples include common disorders such as Alzheimer's and Parkinson's diseases, or rarer disorders such as amyotrophic lateral sclerosis and prion diseases. Despite the fact that the pathological protein component is different in each neurodegenerative disorder, compelling evidence coming from genetic, biophysical and biochemical studies indicate that misfolded proteins are toxic to neurons. In fact, they often expose regions that are normally buried in the native state, leading to aggregation and aberrant interaction with cellular components such as membranes, proteins, or other 
macromolecules. These events may negatively affect neuronal homeostasis, for example, by blocking axonal transport, damaging synaptic endings or sequestering essential proteins, ultimately leading to cell death [2]. Possible strategies for tackling protein aggregation include breaking-up aggregates, increasing their degradation, or blocking their formation by stabilizing the native conformation of the monomeric protein precursors. While the first two have largely been explored in the past, the latter is a relatively new concept, and may possibly provide theoretical and technical advantages. For example, although detailed information about the structure of protein aggregates is rarely available, the three-dimensional organization of the monomeric precursors is often well characterized. A particularly meaningful example is represented by prion diseases. These disorders have the peculiarity of manifesting in a sporadic, inherited or transmissible fashion, and are associated with the conformational conversion of the cellular prion protein $\left(\mathrm{PrP}^{\mathrm{C}}\right)$, a glycoprotein of uncertain function anchored to the outer surface of the plasma membrane, into a misfolded isoform (called $\mathrm{PrP}^{\mathrm{Sc}}$ ) that accumulates in the central nervous system of affected organisms [3]. $\mathrm{PrP}^{\mathrm{Sc}}$ is a proteinaceous infectious particle (prion), capable of multiplying by directly recruiting native conformers of $\mathrm{PrP}^{\mathrm{C}}$, and causing their conformational rearrangement into new $\mathrm{PrP}^{\mathrm{Sc}}$ molecules [4].

The vast majority of experimental strategies aimed at identifying therapeutics for human prion diseases has so far targeted $\operatorname{Pr} \mathrm{P}^{\mathrm{Sc}}$, the most direct, pathologically-relevant form of $\operatorname{PrP}[5]$. However, the structure of $\mathrm{PrP}^{\mathrm{Sc}}$ is poorly defined, and this form is also likely to be heterogeneous in composition and conformation. In fact, one of the most puzzling aspects of prion diseases is the phenomenon of prion strains [6]. It is believed that distinct conformations of $\mathrm{PrP}^{\mathrm{Sc}}$ may explain the unusually wide spectrum of biochemical, neuropathological and clinical features that characterize prion diseases [7]. Prion strains are of particular relevance for the treatment of prion diseases, as their appearance may cause the acquisition of drug resistance to therapeutic treatments $[8,9]$. Indeed, a number of previously discovered anti-prion compounds have been shown to act in a strain-specific fashion, a property that severely limits their therapeutic potentials [10-12].

A possible, perhaps less intuitive strategy to overcome these limitations could be to target $\operatorname{Pr} \mathrm{P}^{\mathrm{C}}$, the common substrate of any prion strain replication. The structure of $\operatorname{PrP}^{\mathrm{C}}$ is known at atomic level resolution, thanks to multiple previous reports employing nuclear magnetic resonance (NMR) or X-ray crystallography [13-15]. This provides a convenient ground to carry out rational drug design campaigns. Moreover, from a theoretical standpoint, a molecule binding to $\mathrm{PrP}^{\mathrm{C}}$ with sufficiently high-affinity might in principle stabilize its folding by reducing the Gibbs free energy. Consequently, the activation energy $(\Delta G)$ required for the unfolding process will increase proportionally, with the result that the rate of formation of any $\mathrm{PrP}^{\mathrm{Sc}}$ strain will be kinetically and thermodynamically disfavored. Small molecules acting with such mechanisms are known as pharmacological chaperones. Interestingly, two or more ligands with independent binding sites on $\operatorname{PrP}^{\mathrm{C}}$ could synergize to completely block the formation of any unfolded form, since the relationship between $\Delta \mathrm{G}$ and the stability constant of a folded polypeptide chain is exponential. In light of these conclusions, $\operatorname{Pr} \mathrm{P}^{\mathrm{C}}$ appears as a convenient molecular target for tackling prion propagation [16]. Is this protein also the right pharmacological target for preventing prion diseases? It is widely agreed that $\mathrm{PrP}^{\mathrm{C}}$ plays a crucial role in the pathogenesis of prion diseases not only by virtue of its ability to serve as substrate for generation of $\mathrm{PrP}^{\mathrm{Sc}}$. In fact, it has been reported that genetically depleting neuronal $\mathrm{PrP}^{\mathrm{C}}$ in mice with established prion infection reverses neuronal loss and progression of clinical signs, despite the continuous production of infectious $\mathrm{PrPSc}^{\mathrm{Sc}}$ by surrounding astrocytes [17]. Similarly, the absence of endogenous $\mathrm{PrP}^{\mathrm{C}}$ renders host brain tissue resistant to the toxic effects of $\mathrm{PrP}^{\mathrm{Sc}}$ emanating from implanted graft tissue [18]. These data indicate that other toxic species, rather than fully aggregated $\mathrm{PrPS}^{\mathrm{Sc}}$, are responsible for the pathology of prion diseases. This conclusion is consistent with a number of previous reports underscoring the distinction between prion infectivity and prion toxicity [19-22]. In particular, recent experiments indicate that accumulation of infectivity and neurodegeneration proceed in distinct chronological and mechanistic phases [23]. While infectivity accumulates relatively rapidly, and requires only a minimum expression of $\operatorname{PrP}^{\mathrm{C}}$, neurodegeneration takes much longer and 
is directly dependent on the amount of $\operatorname{PrP}^{\mathrm{C}}$ expressed in the brain. Taken together, these lines of evidence suggest that an unknown PrP conformer, either "on" or "off" pathway to $\operatorname{PrPSc}$, could be the pathological form in prion diseases. These data provide a possible explanation for the evidence that, with few exceptions $[12,24]$, none of the anti-prion compounds identified so far has shown a substantial effect in vivo. In fact, these molecules could disfavor $\operatorname{PrP}^{\mathrm{Sc}}$ accumulation without hampering the neurotoxicity originating from other toxic conformers. Conversely, stabilizing the folded state of $\mathrm{PrP}^{\mathrm{C}}$ has the potential to block not only $\mathrm{PrP}^{\mathrm{Sc}}$ formation and propagation, but also the appearance of any putative toxic conformer. Another potential advantage of targeting $\operatorname{PrP}^{\mathrm{C}}$ arises from recent observations indicating that $\mathrm{PrP}^{\mathrm{C}}$ may exert a toxicity-transducing activity upon binding to $\mathrm{Pr} \mathrm{P}^{\mathrm{Sc}}$, as well as to various disease-associated, misfolded oligomeric assemblies, such as those formed by the amyloid $\beta(\mathrm{A} \beta)$ peptide, or by the protein alpha-synuclein, linked to Alzheimer's and Parkinson's diseases, respectively [25-29]. Importantly, mice depleted for PrP expression develop normally, with subtle phenotypic changes appearing only later in life, thus suggesting that pharmacological decrease of $\mathrm{PrP}^{\mathrm{C}}$ function could produce little side effects. This conclusion is also supported by the recent identification of loss-of-function PrP alleles in healthy subjects [30]. Overall, these data support the potential value of targeting $\operatorname{PrP}^{\mathrm{C}}$, as this approach may provide therapeutic benefits not only for prion diseases, but possibly also for other neurodegenerative disorders. In this manuscript, we review the main chemical classes reported to act against prion replication in a $\mathrm{PrP}^{\mathrm{C}}$-directed fashion, focusing our discussion on molecules for which binding constant $\left(\mathrm{K}_{\mathrm{D}}\right)$, structural information and anti-prion half-maximal effective concentration $\left(\mathrm{EC}_{50}\right)$ have experimentally been determined (Figure 1).

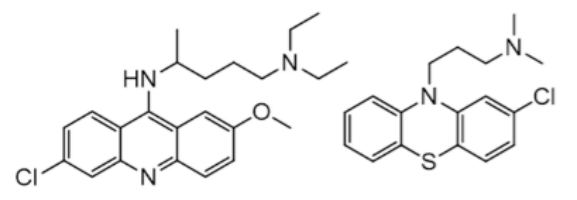

1 , Quinacrine

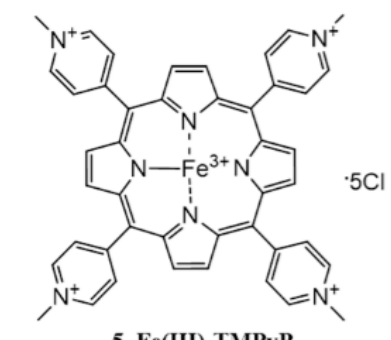

5, Fe(III)-TMPyP
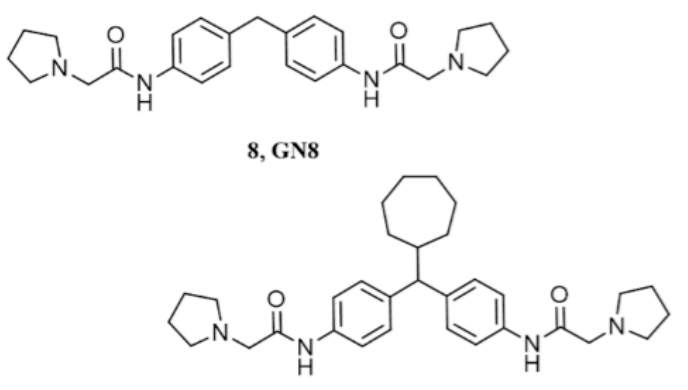

9<smiles>COc1ccc2nc3cc(Cl)ccc3c(Nc3ccc(CN4CCN(C)CC4)cc3)c2c1</smiles>

3
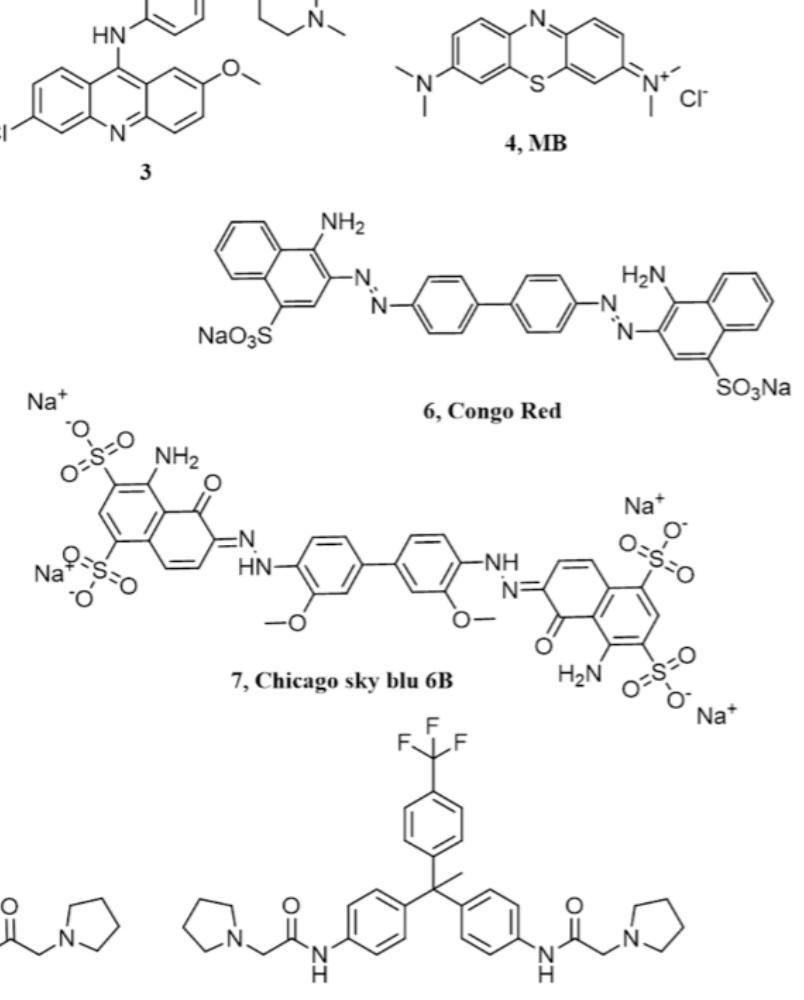

10

Figure 1. Cont. 
<smiles>N#Cc1c(Sc2ccc(Cl)cc2N)nc(N)c(-c2ccco2)c1C#N</smiles>

11<smiles>O=C(O[C@H]1Cc2c(O)cc(O)cc2O[C@H]1c1cc(O)c(O)c(O)c1)c1cc(O)c(O)c(O)c1</smiles><smiles>CCN(CC)CCNC(=O)c1sc(-c2ccc(OC)cc2)nc1-c1ccccc1</smiles>

13<smiles>Cc1ccc2c(c1)C1CCCC(=O)C1N2CC(O)CN1CCCCC1</smiles><smiles>COc1cccc([C@H](C(=O)NC(C)(C)C)N(Cc2ccc(C)cc2)C(=O)Cn2nnc3ccccc32)c1</smiles>

19, NPR-053<smiles>O=C(O[C@H]1Cc2c(O)cc(O)cc2O[C@H]1c1cc(O)c(O)c(O)c1)c1cc(O)c(O)c(O)c1</smiles><smiles>Cc1cc2cc3c(cc2nc1SCCN1CCCCC1)OCCO3</smiles>

17, GJP49<smiles>CCc1ccc2c(c1)CC(CN(CCCN1CCOCC1)C(=O)Nc1cccc(Cl)c1)C(=O)N2</smiles>

20, NPR-056

Figure 1. Chemical structures of the different compounds claimed to directly bind $\operatorname{PrP}^{\mathrm{C}}$.

\section{Acridine and Phenothiazine Derivatives}

Tricyclic derivatives of acridines (compound 1 in Figure 1, quinacrine) and phenothiazines like chlorpromazine (compound $\mathbf{2}$ in Figure 1) were initially reported to be promising candidates for the treatment of prion diseases [31,32]. Indeed, these drugs have already been used in humans for many years, and are known to cross the blood-brain barrier, thus giving hope to their repurposing for prion diseases. The antimalarial agent quinacrine and the antipsychotic drug chlorpromazine showed inhibition of $\mathrm{PrP}^{\mathrm{Sc}}$ formation in prion-infected N2a cells, with $\mathrm{EC}_{50}$ values of $\sim 0.3 \mu \mathrm{M}$ and $\sim 3 \mu \mathrm{M}$, respectively. The acridine derivative quinacrine deserves particular attention, as it showed better potency in cell cultures, and was tested in human trials for prion diseases (more extensively than chlorpromazine, which was tested only in combination with the antimalarial agent). Quinacrine enantiomers showed stereoselectivity against prions, with the (S)-quinacrine exhibiting superior activity in eradicating $\mathrm{PrP}^{\mathrm{Sc}}$ from cells [33]. Unfortunately, despite the promising in vitro profile, no beneficial effects were observed in vivo, using prion-infected rodent models of prion disease [34,35]. In addition to animal models, the activity and safety of quinacrine was assessed in clinical trials in human Creutzfeldt-Jakob disease (CJD) patients, but no effects were observed either on survival at the two-month time point or on the clinical course of the disease [36,37]. Pharmacokinetic studies unveiled that free quinacrine concentration in the brain reached only $\sim \mu \mathrm{M}$, which is a lower value than the cellular $\mathrm{EC}_{50}$ observed in vitro $[11,38]$. These results highlighted the difficulty of translating results obtained by in vitro or cell-based methods to the clinical context. The lack of clinical efficacy of quinacrine against CJD was mainly attributed to metabolic instability, scarce accumulation of the drug into the brain due to active efflux by P-glycoprotein (P-gp) and the formation of drug resistant prion strains [11]. Original studies suggested that the anti-prion activity of quinacrine was directly connected to its ability to modify the lysosomal environment, causing improved clearance of $\operatorname{PrP}^{\mathrm{Pc}}$ [31]. However, later studies reported that quinacrine binds to the globular domain of human recombinant $\operatorname{PrP}$ (residues 121-230), as observed by NMR spectroscopy. Tyr225, Tyr226, and Gln227 of helix 3 (H3) 
were identified as key residues in such ligand-protein interaction (region 1 in Figure 2) [39]. Of note, these experiments were conducted at very high concentrations, and the obtained dissociation constant of quinacrine $\left(\mathrm{K}_{\mathrm{D}}=4.6 \mathrm{mM}\right)$ was about four orders of magnitude higher than its cellular $\mathrm{EC}_{50}$ value (required to clear $\mathrm{PrP}^{\mathrm{Sc}}$ from prion-infected cells in vitro). Similar data $\left(\mathrm{K}_{\mathrm{D}} \sim 1 \mathrm{mM}\right)$ were obtained in another study where quinacrine binding to recombinant human $\operatorname{PrP}$ was analyzed by surface plasmon resonance (SPR) [40], although other SPR studies reported the ability of quinacrine to bind human recombinant $\operatorname{PrP}$ with a $\mathrm{K}_{\mathrm{D}}$ of $15 \mu \mathrm{M}$ [41]. In another report, dynamic light scattering studies and circular dichroism (CD) measurements suggested that quinacrine binding induces a conformational change in PrP, disfavouring $\mathrm{PrP}^{\mathrm{Sc}}$ formation [42]. It is worth noting that the potential of quinacrine as a prion inhibitor has stimulated great interest in the 9-aminoacridine family as therapeutic candidates for prion diseases, and intensive research efforts have been spent on the synthesis, biological evaluation and structure-activity relationship (SAR) studies of quinacrine derivatives [43-46]. In particular, the nature of the aliphatic side-chain on 9-amino group of the tricyclic scaffold was found to be one key feature for enhancing binding affinity to PrP, PAMPA permeability and inhibition of $\operatorname{PrP} \mathrm{P}^{\mathrm{Sc}}$ accumulation. As an example, a quinacrine derivative (compound 3 in Figure 1) showed improved anti-prion activity, as compared to the parent compound, across different prion-infected murine cell models (ScN2a, N167, F3). In addition, this compound exhibited stronger binding affinity by SPR, and seemed to be a weaker substrate for P-gp [46]. However, more recent SPR- and NMR-based studies have highlighted a non-specific binding interaction of quinacrine to $\operatorname{PrP}^{\mathrm{C}}$, reiterating the original observation that its mode of action involves PrP-independent mechanisms [47,48].

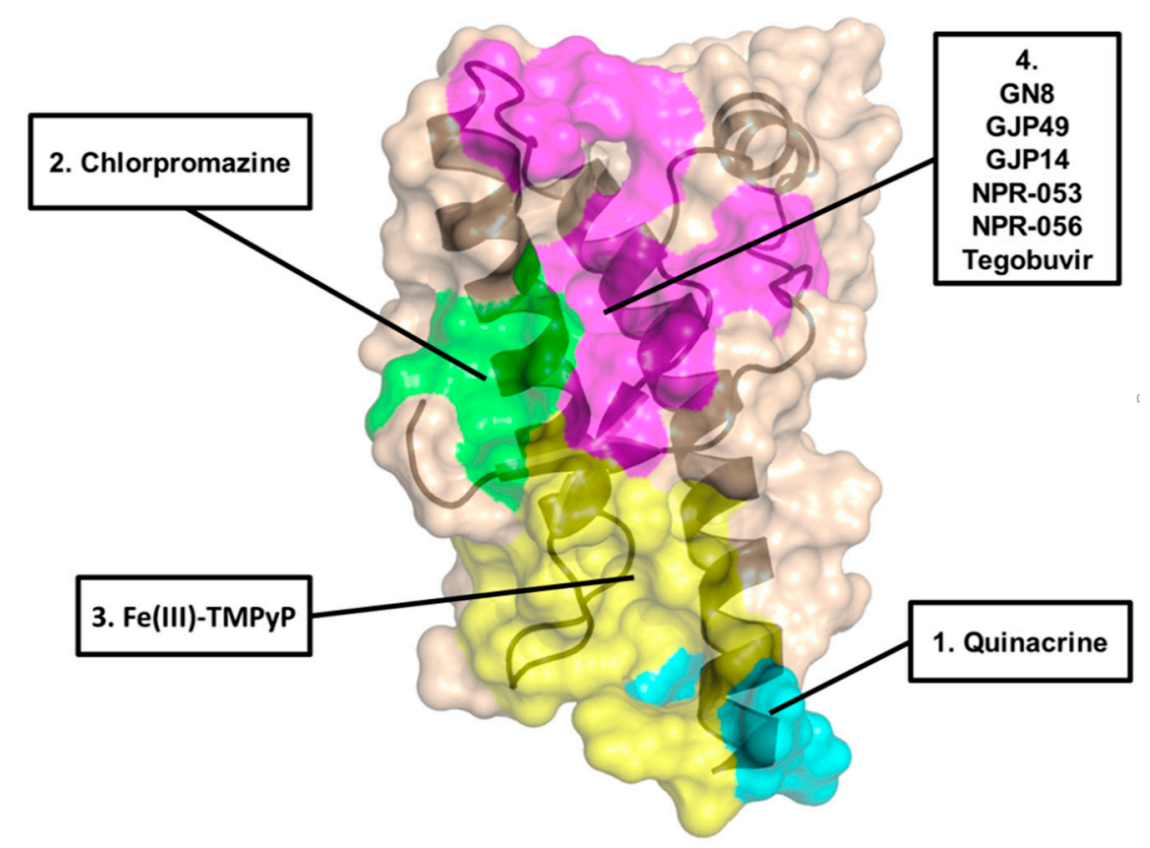

Figure 2. Visualization of the proposed binding regions for the different $\operatorname{Pr} \mathrm{P}^{\mathrm{C}}$ ligands (indicated).

Similarly to quinacrine, the direct binding of phenothiazine derivative chlorpromazine to $\operatorname{PrP}^{\mathrm{C}}$ was originally investigated by NMR [39] and SPR [41], showing a weaker interaction with recombinant PrP, as compared to quinacrine. A subsequent study based on NMR and X-ray crystallography (PDB ID 4MA8) reported a precise binding site of phenothiazines on $\operatorname{PrP}^{\mathrm{C}}$, located in a hydrophobic pocket formed by helix-2 (H2) and the two anti-parallel $\beta$-sheets (S1 and S2; region 2 in Figure 2) [49]. The data also indicated that an unexpected intramolecular reorganization of the $\mathrm{N}$-terminal, unstructured tail of $\mathrm{PrP}^{\mathrm{C}}$ around the $\mathrm{C}$-terminal domain, through the formation of a hydrophobic anchor, directly suggesting a mechanism by which phenothiazines may act as pharmacological chaperone of $\operatorname{PrPC}$. Unfortunately, the study did not provide an affinity value for the binding of phenothiazines to $\operatorname{Pr} \mathrm{PC}^{\mathrm{C}}$. 
Such value was instead precisely defined in the following report, employing SPR and dynamic mass redistribution (DMR) [50]. The results confirmed original observations indicating a weak interaction of chlorpromazine to $\mathrm{PrP}^{\mathrm{C}}$, with an estimated $\mathrm{K}_{\mathrm{D}}$ higher than $400 \mu \mathrm{M}$, compatible with data collected in the original study [49], which employed millimolar concentrations of chlorpromazine to carry out NMR and X-ray crystallography experiments. A $K_{D}$ value in the high micromolar concentration range is incompatible with the reported anti-prion effects of chlorpromazine in cells, indicating that its mode of action is independent from direct PrP binding [50]. Moreover, chlorpromazine also failed to inhibit prion replication in vitro (by the protein misfolding cyclic amplification reaction, PMCA), as instead it would be expected for a pharmacological chaperone of $\mathrm{PrP}^{\mathrm{C}}$. Interestingly, the same study reported compelling evidence indicating that the mechanism of action underlying the anti-prion effect of chlorpromazine is related to the previously known ability of the compound to inhibit clathrin-mediated endocytosis, leading to decreased levels of $\operatorname{PrP}^{\mathrm{C}}$ at the cell surface. Consistent with this conclusion, two inhibitors of dynamins, proteins involved in the regulation of the scission of membrane vesicles, and recently reported to be targeted by chlorpromazine [51], mimicked $\mathrm{PrP}^{\mathrm{C}}$-relocalizing effects, and blocked the replication of two different prion strains in cell cultures [50]. An additional recent work provided evidence for a chlorpromazine-induced redistribution of $\mathrm{PrP}^{\mathrm{Sc}}$ from the endocytic-recycling pathway to the lysosomal compartment, an effect that could be the direct consequence of the relocalization of $\mathrm{PrP}^{\mathrm{C}}$ from the cell surface [52].

Methylene Blue (MB, compound 4 in Figure 1), a phenothiazine derivative, has been shown to affect the kinetics of $\mathrm{PrP}$ oligomerization by binding to a surface cleft on $\mathrm{PrP}^{\mathrm{C}}$ [53]. Using size exclusion chromatography, static light scattering, differential scanning calorimetry and transmission electron microscopy, the authors studied the influence of methylene blue on the oligomerization and fibrillation of human, ovine and murine recombinant PrP, observing a decrease in oligomerization kinetics and overall levels. NMR experiments mapped MB binding sites in a surface cleft delimited by residues belonging to S1-H1 and H2-H3 loops, and H1, H2 and H3 helices (residues Asn146, Asn156, Tyr160, Lys188, Thr191, Val192, Thr194, Thr195, Gln215). Of note, MB has been investigated as potential therapeutic agent in other proteinopathies [54-57], which is consistent with the number of potential applications that have been tested for this compound, likely reflecting its ability to engage non-specific interactions with a broad range of proteins.

\section{Cyclic Tetrapyrroles}

Cyclic tetrapyrroles, planar aromatic ring systems coordinating metal ions and bearing pendants of different chemical nature, were originally found to be effective in prion-infected cells, and later claimed to act by directly binding to $\operatorname{PrP}^{\mathrm{C}}[58,59]$. In particular, by employing isothermal titration calorimetry (ITC), the cationic tetrapyrrole Fe(III)-TMPyP (compound 5 in Figure 1) was shown to bind human recombinant $\operatorname{PrP}$ in the C-terminal, globular domain $\left(\mathrm{K}_{\mathrm{D}}=4.52 \mu \mathrm{M}\right)$, which was consistent with its cellular $\mathrm{EC}_{50}$ of $1.6 \mu \mathrm{M}$ in cells (as tested in rocky mountain laboratory, RML-infected PK1 cells) and the range of concentrations $(1-11 \mu \mathrm{M})$ active in the protein-misfolding cyclic amplification (PMCA) reaction [48]. NMR studies allowed the identification of the binding site of Fe(III)-TMPyP on human $\mathrm{PrP}$, with key interacting residues clustered at the $\mathrm{C}$ terminus of $\mathrm{H} 3$ and in the loop between residues 160 and 180 (region 3 in Figure 2). Importantly, Fe(III)-TMPyP, or highly similar porphyrins, also showed the ability to inhibit the cytotoxic activity of a mutant $\operatorname{PrP}$ carrying a deletion in the central region ( $\Delta 105-125)$, abrogated the $\mathrm{PrP}^{\mathrm{C}}$-mediated synaptotoxic effects of $\mathrm{A} \beta$ oligomers in primary hippocampal neurons, and significantly prolonged survival time in prion-infected mice $[60,61]$. Unfortunately, the therapeutic potentials of porphyrins like Fe(III)-TMPyP is dampened by their poor pharmacokinetic properties, such as possible non-specific interactions with plasma proteins, and unlikelihood to cross the blood-brain barrier [62]. However, as assayed by in vitro and cell-based tests, these compounds appear as the most effective pharmacological chaperones of $\mathrm{PrP}^{\mathrm{C}}$, and have already been employed to gain insights into the physiological activity of $\operatorname{PrPC}^{\mathrm{C}}$, and its functional connection to neurodegenerative pathways. Performing extensive pharmacokinetic profiling of this 
class of molecules, coupled to chemical optimization efforts and/or innovative ways of delivery to the central nervous system, could provide effective therapeutic strategies for prion diseases, and possibly other neurodegenerative disorders linked to the toxicity-transducing activity of $\operatorname{PrP}^{\mathrm{C}}$.

\section{Diazo Dyes}

The diazo dye Congo red (compound 6 in Figure 1) was found to possess anti-prion activity in cells and in vivo, using scrapie-infected golden Syrian hamsters [63-67]. In particular, Congo red prevented the formation and accumulation of $\mathrm{PrP}^{\mathrm{Sc}}$ in neuroblastoma cells with an $\mathrm{EC}_{50}$ of about $0.015 \mu \mathrm{M}$. The binding of Congo red to human recombinant PrP was investigated by SPR, and showed a $\mathrm{K}_{\mathrm{D}}$ value of $1.6 \mu \mathrm{M}$ [40]. However, other studies reported that, in physiological conditions, the molecule binds non-specifically to $\mathrm{PrP}^{\mathrm{C}}$ as an aggregated polyanion [47]. Congo Red itself has a number of shortfalls, such as non-specific interactions with various macromolecules, self-polymerization, toxicity and poor permeability through BBB. For this reason, several Congo red derivatives were designed and synthesized to improve the pharmacological profile of the compound, and a number of analogues showed anti-prion effects at nanomolar concentrations, even though no information about their possible interaction with $\mathrm{PrPC}^{\mathrm{C}}$ was reported [68-70].

\section{Chicago Sky Blue 6B}

This molecule emerged from a screen of 1200 approved drugs and pharmacological tool compounds (Prestwick Chemical Library) based on a fluorescence polarization (FP) assay, and aimed at identifying compounds capable of inhibiting the binding of $\mathrm{A} \beta$ oligomers to $\operatorname{PrP}^{\mathrm{C}}$ [71]. Chicago Sky Blue $6 \mathrm{~B}$ (compound 7 in Figure 1) was identified as the best-ranked candidate, with $\mathrm{EC}_{50}$ values of $0.41 \mu \mathrm{M}$ and $19.7 \mu \mathrm{M}$ in FP and ELISA assays, respectively. ITC experiments confirmed that Chicago Sky Blue 6B is able to interact with human recombinant $\operatorname{PrP}$, with a $\mathrm{K}_{\mathrm{D}}$ value of $0.55 \mu \mathrm{M}$. Importantly, the compound did not bind a PrP construct containing only residues 119-231, indicating that its binding site lies within the N-terminal, unstructured tail of the protein. Since A $\beta$ oligomers are known to bind $\operatorname{PrP}$ in the same region, the data suggested that Chicago Sky Blue 6B may act by a mechanism of direct competition. Of note, Chicago Sky Blue 6B also showed anti-prion effects in RML-infected N2a cells, with $\mathrm{EC}_{50}$ values in the low micromolar range, and in absence of evident cytotoxicity. At the time this manuscript was prepared, no other studies have employed Chicago Sky Blue 6B in the context of prion diseases.

\section{Diphenylmethane Derivatives}

A compound known as GN8 (compound 8 in Figure 1) emerged from an in silico, dynamics-based drug screen of $\sim 320,000$ compounds aimed at directly identifying pharmacological chaperones for $\operatorname{PrPC}$ [72]. In vitro validation studies estimated the affinity of GN8 for recombinant, mouse PrP in the low micromolar range $(\mathrm{KD} \sim 5 \mu \mathrm{M})$. Heteronuclear NMR and molecular modeling mapped the PrP binding region of GN8 at the C-terminal domain, particularly involving residues N159 and E196 (region 4 in Figure 2). Furthermore, the authors employed CD in a thermal-denaturation assay to confirm that the binding of GN8 stabilizes the $\operatorname{PrP}^{\mathrm{C}}$ conformation significantly $(\Delta \Delta \mathrm{H}=6.7 \mathrm{kcal} / \mathrm{mol}$ ). Biological validation showed that GN8 efficiently inhibits prion replication in cells, with an estimated $\mathrm{EC}_{50}$ of $\sim 1.35 \mu \mathrm{M}$. Importantly, GN8 was also found to prolong the survival of prion-infected mice, thus confirming the effective anti-prion activity of this molecule. Subsequent studies focused on the synthesis and evaluation of anti-prion effects for a series of GN8 analogues with the main objective of generating a SAR profile [73]. Two derivatives (compounds $\mathbf{9}$ and $\mathbf{1 0}$ in Figure 1) were found to be approximately three times more potent than the parent compound, with $\mathrm{EC}_{50}$ values around $0.5 \mu \mathrm{M}$, in absence of detectable toxicity. CD-coupled thermal-denaturation assays indicated that one of these molecules significantly stabilized recombinant $\operatorname{PrP}$, with a degree of stabilization by this ligand approximately doubled, as compared with that of GN8 $(\Delta \Delta \mathrm{H}=14.2 \mathrm{kcal} / \mathrm{mol})$. Binding was also confirmed by SPR. According to these data, GN8 and its derivatives appear as promising 
pharmacological chaperones of $\operatorname{Pr} \mathrm{P}^{\mathrm{C}}$. However, it is worth noting that two subsequent studies failed to confirm binding of GN8 to mouse or human recombinant PrP, using a battery of biophysical techniques $[48,60]$. Such experimental discrepancy is currently unresolved.

\section{Pyridine Dicarbonitriles}

Four pyridine dicarbonitrile analogues, originally identified as anti-prion compounds in prion-infected cells [74], were later tested for their direct interaction with $\mathrm{PrP}^{\mathrm{C}}$ using SPR [41]. One derivative (compound 11 in Figure 1 ) showed anti-prion activity $\left(E_{50}\right.$ values $\sim 20 \mu \mathrm{M}$ ) and detectable binding to recombinant PrP. This observation justified the following efforts to generate small libraries of pyridine dicarbonitrile derivatives, which were then tested by SPR for binding to $\operatorname{PrP} \mathrm{P}^{\mathrm{C}}$, and in cellular assays to evaluate anti-prion activity [75,76]. Unexpectedly, no direct correlation was observed between binding to $\mathrm{PrP}^{\mathrm{C}}$ and anti-prion efficacy, with the most potent anti-prion pyridine dicarbonitrile showing either weak or no binding to $\operatorname{PrP}^{\mathrm{C}}$. Collectively, these data suggested that pyridine dicarbonitrile likely inhibit prion replication in a $\mathrm{PrP}^{\mathrm{C}}$-independent fashion.

\section{Diarylthiazoles}

The same team originally involved in the study on the dicarbonitrile derivatives also reported the synthesis and screening of 2,4-diarylthiazole-based compounds as potential anti-prion agents [77,78]. The authors stated that original 2,4-diarylthiazole scaffold was identified as a PrP ligand through a virtual screening campaign, although details of such screening were not described. SPR was then employed to test the binding of several derivatives to mouse or human recombinant PrP. Only one compound (compound 12 in Figure 1) showed a high-affinity interaction with PrP. All the molecules were also tested in prion-infected SMB cells, but once again no correlation was found between PrP binding and anti-prion activity in cells. A second series of reverse amide 2,4-diarylthiazole-based anti-prion compounds was later reported in a following study. The molecules were first tested for prion inhibition in SMB cells and then evaluated for binding to recombinant PrP, as assayed by SPR. Among the compounds active in cells, one derivative (compound 13 in Figure 1) $\left(\mathrm{EC}_{50}=4 \mu \mathrm{M}\right.$ ) also showed affinity for PrP, although a careful evaluation of SPR data suggested the possibility of a non-specific interaction. Overall, these studies highlighted a general lack of correlation between anti-prion activity and PrP binding for 2,4-diarylthiazole-based compounds, suggesting that other PrP-independent modes of action account for the anti-prion effects of this chemical class.

\section{Natural Polyphenols}

In search of small molecules able to interfere with prion propagation, another study screened a collection of natural compounds with proven activity against amyloid formation in vitro $[79,80]$. The major polyphenols component of green tea, i.e., epigallocatechin gallate (EGCG, compound $\mathbf{1 4}$ in Figure 1) and its stereoisomer gallocatechin gallate (GCG, compound 15 in Figure 1), showed anti-prion activity in prion-infected N2a cells. The direct interaction of EGCG with recombinant $\operatorname{PrP}$ (residues 90-232) was experimentally tested by ITC, showing a strong affinity $\left(K_{D}=0.13 \mu \mathrm{M}\right)$ and a remarkable stabilization effect $(\Delta \mathrm{H}$ of $-43 \mathrm{KJ})$. Further experiments on the effect of EGCG binding revealed an unexpected destabilization effect of the compound on the native conformation of $\operatorname{PrPC}$, inducing its rapid transition into detergent-insoluble species, which were rapidly degraded intracellularly. The authors also observed that the anti-prion activity depended on the gallate side chain and the three hydroxyl groups of the trihydroxyphenyl side chain. Unfortunately, a subsequent study characterized the binding properties of EGCG to PrPC by SPR and NMR, concluding that the compound binds to the protein in a non-specific fashion [47]. These results dampened the enthusiasm for the treatment of prion diseases with EGCG-like polyphenols. 


\section{Miscellanea}

Several structurally diverse compounds identified by virtual screening campaigns on the proposed binding pocket for GN8 have been claimed to be specific $\mathrm{PrP}^{\mathrm{C}}$ ligands, capable of acting as chemical chaperones. In 2009, a virtual screening study led to the selection of 205 commercially available compounds to be evaluated for their effects on the $\mathrm{PrP}^{\mathrm{C}}$ conversion process [81]. Ex vivo-experiments identified 24 non-cytotoxic molecules that significantly inhibited prion replication in GT-FK cells, at a concentration of $10 \mu \mathrm{M}$. To further elucidate their mechanism of action, the authors measured the binding affinity for recombinant PrP by SPR, and then compared anti-prion activity in cells with affinity values. Eleven compounds were classified as PrP-directed anti-prion compounds; for example, for a molecule named GJP14 (compound 16 in Figure 1), the authors reported an $\mathrm{EC}_{50}=8.54 \mu \mathrm{M}$ [82]. Compounds GJP14 and GJ49 (compound 17 in Figure 1) were further characterized for their binding properties by SPR and NMR (for example, for GJ49 $\mathrm{K}_{\mathrm{D}}=50.8 \mu \mathrm{M}$ ), showing a ligand-binding pocket in the C-terminal, globular domain of $\operatorname{PrP}^{\mathrm{C}}$ (region 4 in Figure 2) [47].

A related study performed a 3D pharmacophore-based virtual screen of an in-house chemical library, and selected 37 potential anti-prion compounds to be assessed by cell-based and SPR-based assays [83]. The results identified a molecule named BMD42-29 (a benoxazole derivative whose structure was not disclosed) as the best hit among the screened molecules, with an $\mathrm{EC}_{50}$ value against prion replication in cells in the low micromolar range $(<5 \mu \mathrm{M})$. Of note, in prion-infected N2a cells, the compound did not produce a marked reduction in total PrP levels. SPR experiments revealed that BMD42-29 had strong binding affinity to $\operatorname{PrPC}^{\mathrm{C}}\left(\mathrm{K}_{\mathrm{D}}=21.5 \mu \mathrm{M}\right)$, with kinetic rates characterized by rapid association and slow dissociation constants. The predicted binding mode of BMD42-29 was located in the same pocket of GN8, and was characterized by two hydrogen bonds with Asn159 and Glu196, and hydrophobic interactions with Leu130 and Arg156. The author concluded that BMD42-29 may act by stabilizing $\operatorname{PrP}^{\mathrm{C}}$, thus inhibiting its pathological conformational change to $\operatorname{PrP}^{\mathrm{SC}}$. In 2016, another group built a platform called "NAGARA", aimed at unifying docking simulation, molecular dynamics and quantum chemistry to perform large-scale screening of commercially available compounds [84]. One hundred hits predicted in silico to bind $\mathrm{PrP}^{\mathrm{C}}$ were subjected to cell-based validation to evaluate anti-prion effects. Tegobuvir (previously known as an anti-hepatitis $C$ agent, compound $\mathbf{1 8}$ in Figure 1) emerged as one of the most promising candidates, with an estimated $\mathrm{EC}_{50}$ of $1.7 \mu \mathrm{M}$, as assayed in immortalized neuronal mouse cells persistently infected with the human Fukuoka-1 prion strain. The molecule also showed detectable binding to $\operatorname{PrP}^{C}$ in the low micromolar range $\left(K_{D}=19 \mu \mathrm{M}\right.$, region 4 in Figure 2). In the same year, by coupling docking simulations of a large virtual library ( $\sim 200 \mathrm{~K}$ compounds) and binding interaction analyses, another group reported the identification of 96 novel small molecules capable of binding $\mathrm{PrP}^{\mathrm{C}}$ in the same pocket of GN8 [85]. The ability of the in silico-predicted hits to target $\operatorname{PrP}^{\mathrm{C}}$ was evaluated by SPR and thermal shift assay (TSA), whereas their anti-prion effects were estimated using persistently infected cells and animal models of prion diseases. Compounds NPR-053 (compound 19 in Figure 1) and NPR-056 (compound 20 in Figure 1) emerged as the most promising candidates, in light of their ability to reduce $\mathrm{PrP}^{\mathrm{Sc}}$ levels in cultured cells, with $\mathrm{EC}_{50}$ values of $7.68 \mu \mathrm{M}$ and $3.72 \mu \mathrm{M}$, respectively. Both SPR and TSA provided evidence for a direct binding of both compounds to $\operatorname{PrP}^{\mathrm{C}}$ (region 4 in Figure 2), with NPR-053 inducing the strongest stabilization effect on $\operatorname{PrP}^{\mathrm{C}}$ native folding $\left(\Delta \mathrm{T}_{\mathrm{m}}=2.69^{\circ} \mathrm{C}\right)$. All of these compounds represent promising candidate pharmacological chaperones for $\mathrm{PrP}^{\mathrm{C}}$, although further experimental validation is needed before considering them as promising therapeutic agents for prion diseases. 
Table 1. Summary of main chemical scaffolds reported to exert anti-prion effects by directly targeting $\operatorname{PrP}^{\mathrm{C}}$.

\begin{tabular}{|c|c|c|c|c|c|}
\hline Chemical Scaffold & $\begin{array}{l}\text { Compound } \\
\text { (Figure 1) }\end{array}$ & $\mathbf{K}_{\mathbf{D}}$ * & $\mathrm{EC}_{50} * *$ & Effect In Vivo *** & Conclusions \\
\hline Acridine derivatives & 1 & $\sim 1 \mathrm{mM}$ & $\sim 0.3 \mu \mathrm{M}$ & Not significant & Primary effects are PrP-independent \\
\hline $\begin{array}{l}\text { Phenothiazine } \\
\text { derivatives }\end{array}$ & 2 & $>400 \mu \mathrm{M}$ & $\sim 3 \mu \mathrm{M}$ & Not significant & $\begin{array}{l}\text { Likely acting by inducing } \mathrm{PrPC}^{\mathrm{C}} \\
\text { re-localization from the cell surface }\end{array}$ \\
\hline Tetrapyrroles & 5 & $4.52 \mu \mathrm{M}$ & $1.6 \mu \mathrm{M}$ & $\begin{array}{l}\text { Prolongation of survival time in } \\
\text { prion-infected mice }\end{array}$ & $\begin{array}{l}\text { Low specificity and possible poor } \\
\text { pharmacokinetics }\end{array}$ \\
\hline Diazo dyes & 6 & $1.6 \mu \mathrm{M}$ & $0.015 \mu \mathrm{M}$ & Not available & Low specificity \\
\hline Chicago sky blue 6B & 7 & $0.55 \mu \mathrm{M}$ & Low $\mu \mathrm{M}$ & Not available & Need confirmation \\
\hline $\begin{array}{l}\text { Diphenylmethane } \\
\text { derivatives }\end{array}$ & 8 & $5 \mu \mathrm{M}$ & $1.35 \mu \mathrm{M}$ & $\begin{array}{l}\text { Prolongation of survival time in } \\
\text { prion-infected mice }\end{array}$ & $\operatorname{PrP}^{\mathrm{C}}$ binding not reproduced in some study \\
\hline Pyridine Dicarbonitriles & 11 & $\sim 20 \mu \mathrm{M}$ & $18.6 \mu \mathrm{M}$ & Not available & $\begin{array}{l}\text { No correlation between anti-prion activity } \\
\text { and binding to } \mathrm{PrP}^{\mathrm{C}}\end{array}$ \\
\hline Diarylthiazoles & 13 & $3.8 \mu \mathrm{M}$ & $4 \mu \mathrm{M}$ & Not available & $\begin{array}{l}\text { No correlation between anti-prion activity } \\
\text { and binding to } \mathrm{PrPC}\end{array}$ \\
\hline Natural polyphenols & 14 & $0.13 \mu \mathrm{M}$ & - & Not available & Possible non-specific interaction with $\operatorname{PrPC}$ \\
\hline \multirow{2}{*}{ Miscellanea } & 17 & $50.8 \mu \mathrm{M}$ & Not available & Not available & Need confirmation \\
\hline & 20 & $19 \mu \mathrm{M}$ & $3.72 \mu \mathrm{M}$ & Not available & Need confirmation \\
\hline
\end{tabular}

${ }^{*}$ Reported affinity for $\mathrm{PrP}^{\mathrm{C}} ;{ }^{* *}$ Anti-prion activity measured in cell cultures; ${ }^{* * *}$ Tested in prion-infected rodent models and/or human patients. 


\section{Conclusions}

Mounting evidence indicates that the accumulation of $\mathrm{PrP}^{\mathrm{Sc}}$ alone could not account for the wide spectrum of neurotoxic events occurring in prion diseases. Instead, an unexpected role for $\operatorname{PrP}^{\mathrm{C}}$ as toxicity-transducer receptor for $\mathrm{PrP}^{\mathrm{Sc}}$ and other disease-associated misfolded oligomeric assemblies, such as $A \beta$ and alpha-synuclein, has raised great interest for targeting this protein pharmacologically. In this manuscript, we reviewed previous efforts to identify $\operatorname{PrP}^{\mathrm{C}}$-directed compounds, taking into account limitations and reproducibility of each experimental attempt. A number of chemical scaffolds, identified by combining computational methods with biochemical, biophysical and cell-based assays, have been claimed to exert anti-prion effects by targeting $\operatorname{PrPC}^{\mathrm{C}}$ (Table 1). Some of these molecules, such as the cationic tetrapyrrole $\mathrm{Fe}(\mathrm{III})-\mathrm{TMPyP}$, provide a proof-of-principle for targeting $\mathrm{PrPC}$ pharmacologically. Others, such as chlorpromazine, reveal unexpected mechanisms to counteract prion replication by lowering cell surface $\operatorname{PrP}^{\mathrm{C}}$. However, the vast majority of compounds show inconsistencies between affinity for $\mathrm{PrP}^{\mathrm{C}}$ and biologically-active concentrations, low binding specificity, and/or lack of reproducibility. At the moment, none of these molecules appear as immediate candidates for clinical testing in the near future. Moreover, the great deal of negative data eventually provide further support to the notion that the vast majority of anti-prion molecules identified so far exert their activity through unknown targets, or by altering the homeostasis of $\operatorname{PrP}^{\mathrm{C}}$, rather than binding the protein directly. What could be the reason for such a lack of success in identifying small ligands of $\mathrm{PrP}^{\mathrm{C}}$ ? We believe the answer to this question may lie in a few, non-mutually exclusive possibilities. First, the screening techniques employed so far (e.g., in silico approaches coupled to biophysical assays) could have been inadequate for effectively identifying $\mathrm{PrP}^{\mathrm{C}}$-directed molecules. Moreover, most of the approaches reviewed in this manuscript relied on recombinant $\operatorname{PrP}$ for testing the binding of small molecules, while physiological, post-translational modifications of the protein (sugar and lipid moieties) may heavily influence ligand binding. It is also possible that a single $\operatorname{PrP}^{\mathrm{C}}$ ligand will never be truly effective in preventing prion replication, since its stabilization effect on $\operatorname{PrP}^{\mathrm{C}}$ folding could be counteracted by the strong affinity of $\operatorname{PrP}^{\mathrm{Sc}}$ for its substrate. In this scenario, testing the combination of two or three ligands binding $\operatorname{PrP}^{\mathrm{C}}$ in distinct pockets may produce the expected anti-prion effects. Ultimately, it is also possible that $\operatorname{PrP}^{\mathrm{C}}$ simply lies among the proteins that can be classified as "undraggable". We like to believe that the latter conclusion will soon be refuted by direct experimental evidence.

Acknowledgments: The study was supported by a Young Investigator Award from the Italian Ministry of Health (GR-2010-2312769), and a grant from the CJD Foundation. EB is an Assistant Telethon Scientist at the Dulbecco Telethon Institute (TCP14009, Fondazione Telethon, Italy).

Author Contributions: M.L.B. and E.B. conceived the main aspects of the review, M.L.B., N.I., S.B., V.C. and E.B. wrote the paper.

Conflicts of Interest: The authors declare no conflict of interest. M.L.B. and E.B. are co-founders of Sibylla Biotech (www.sibyllabiotech.it), a startup company focused on developing new therapeutics for neurodegenerative disorders, including prion diseases.

\section{References}

1. Chiti, F.; Dobson, C.M. Protein misfolding, functional amyloid, and human disease. Annu. Rev. Biochem. 2006, 75, 333-366. [CrossRef] [PubMed]

2. Bucciantini, M.; Giannoni, E.; Chiti, F.; Baroni, F.; Formigli, L.; Zurdo, J.; Taddei, N.; Ramponi, G.; Dobson, C.M.; Stefani, M. Inherent toxicity of aggregates implies a common mechanism for protein misfolding diseases. Nature 2002, 416, 507-511. [CrossRef] [PubMed]

3. Prusiner, S.B. Biology and genetics of prions causing neurodegeneration. Annu. Rev. Genet. 2013, 47, 601-623. [CrossRef] [PubMed]

4. Prusiner, S.B. Novel proteinaceous infectious particles cause scrapie. Science 1982, 216, 136-144. [CrossRef] [PubMed] 
5. Giles, K.; Olson, S.H.; Prusiner, S.B. Developing therapeutics for prp prion diseases. Cold Spring Harbor Perspect. Med. 2017, 7, a023747. [CrossRef] [PubMed]

6. Baskakov, I.V. The many shades of prion strain adaptation. Prion 2014, 8, 27836. [CrossRef]

7. Espinosa, J.C.; Nonno, R.; Di Bari, M.; Aguilar-Calvo, P.; Pirisinu, L.; Fernandez-Borges, N.; Vanni, I.; Vaccari, G.; Marin-Moreno, A.; Frassanito, P.; et al. PrPc governs susceptibility to prion strains in bank vole, while other host factors modulate strain features. J. Virol. 2016, 90, 10660-10669. [CrossRef] [PubMed]

8. Collinge, J. Medicine. Prion strain mutation and selection. Science 2010, 328, 1111-1112. [CrossRef] [PubMed]

9. Li, J.; Browning, S.; Mahal, S.P.; Oelschlegel, A.M.; Weissmann, C. Darwinian evolution of prions in cell culture. Science 2010, 327, 869-872. [CrossRef] [PubMed]

10. Sim, V.L. Prion disease: Chemotherapeutic strategies. Infect. Disord. Drug Targets 2012, 12, $144-160$. [CrossRef] [PubMed]

11. Ghaemmaghami, S.; Ahn, M.; Lessard, P.; Giles, K.; Legname, G.; DeArmond, S.J.; Prusiner, S.B. Continuous quinacrine treatment results in the formation of drug-resistant prions. PLoS Pathog. 2009, 5, e1000673. [CrossRef] [PubMed]

12. Giles, K.; Berry, D.B.; Condello, C.; Hawley, R.C.; Gallardo-Godoy, A.; Bryant, C.; Oehler, A.; Elepano, M.; Bhardwaj, S.; Patel, S.; et al. Different 2-aminothiazole therapeutics produce distinct patterns of scrapie prion neuropathology in mouse brains. J. Pharmacol. Exp. Ther. 2015, 355, 2-12. [CrossRef] [PubMed]

13. Riek, R.; Hornemann, S.; Wider, G.; Billeter, M.; Glockshuber, R.; Wüthrich, K. NMR structure of the mouse prion protein domain $\operatorname{PrP}(121-231)$. Nature 1996, 382, 180-182. [CrossRef] [PubMed]

14. Zahn, R.; Liu, A.; Luhrs, T.; Riek, R.; von Schroetter, C.; Lopez Garcia, F.; Billeter, M.; Calzolai, L.; Wider, G.; Wüthrich, K. NMR solution structure of the human prion protein. Proc. Natl. Acad. Sci. USA 2000, 97, 145-150. [CrossRef] [PubMed]

15. Antonyuk, S.V.; Trevitt, C.R.; Strange, R.W.; Jackson, G.S.; Sangar, D.; Batchelor, M.; Cooper, S.; Fraser, C.; Jones, S.; Georgiou, T.; et al. Crystal structure of human prion protein bound to a therapeutic antibody. Proc. Natl. Acad. Sci. USA 2009, 106, 2554-2558. [CrossRef] [PubMed]

16. Nicoll, A.J.; Collinge, J. Preventing prion pathogenicity by targeting the cellular prion protein. Infect. Disord. Drug Targets 2009, 9, 48-57. [CrossRef] [PubMed]

17. Mallucci, G.R.; White, M.D.; Farmer, M.; Dickinson, A.; Khatun, H.; Powell, A.D.; Brandner, S.; Jefferys, J.G.; Collinge, J. Targeting cellular prion protein reverses early cognitive deficits and neurophysiological dysfunction in prion-infected mice. Neuron 2007, 53, 325-335. [CrossRef] [PubMed]

18. Brandner, S.; Isenmann, S.; Raeber, A.; Fischer, M.; Sailer, A.; Kobayashi, Y.; Marino, S.; Weissmann, C.; Aguzzi, A. Normal host prion protein necessary for scrapie-induced neurotoxicity. Nature 1996, 379, 339-343. [CrossRef] [PubMed]

19. Biasini, E.; Medrano, A.Z.; Thellung, S.; Chiesa, R.; Harris, D.A. Multiple biochemical similarities between infectious and non-infectious aggregates of a prion protein carrying an octapeptide insertion. J. Neurochem. 2008, 104, 1293-1308. [CrossRef] [PubMed]

20. Biasini, E.; Seegulam, M.E.; Patti, B.N.; Solforosi, L.; Medrano, A.Z.; Christensen, H.M.; Senatore, A.; Chiesa, R.; Williamson, R.A.; Harris, D.A. Non-infectious aggregates of the prion protein react with several PrPsc-directed antibodies. J. Neurochem. 2008, 105, 2190-2204. [CrossRef] [PubMed]

21. Chiesa, R.; Harris, D.A. Prion diseases: What is the neurotoxic molecule? Neurobiol. Dis. 2001, 8, 743-763. [CrossRef] [PubMed]

22. Aguzzi, A.; Falsig, J. Prion propagation, toxicity and degradation. Nat. Neurosci. 2012, 15, 936-939. [CrossRef] [PubMed]

23. Sandberg, M.K.; Al-Doujaily, H.; Sharps, B.; Clarke, A.R.; Collinge, J. Prion propagation and toxicity in vivo occur in two distinct mechanistic phases. Nature 2011, 470, 540-542. [CrossRef] [PubMed]

24. Wagner, J.; Ryazanov, S.; Leonov, A.; Levin, J.; Shi, S.; Schmidt, F.; Prix, C.; Pan-Montojo, F.; Bertsch, U.; Mitteregger-Kretzschmar, G.; et al. ANLE138B: A novel oligomer modulator for disease-modifying therapy of neurodegenerative diseases such as prion and Parkinson's disease. Acta Neuropathol. 2013, 125, 795-813. [CrossRef] [PubMed]

25. Elezgarai, S.R.; Biasini, E. Common therapeutic strategies for prion and alzheimer's diseases. Biol. Chem. 2016, 397, 1115-1124. [CrossRef] [PubMed] 
26. Lauren, J.; Gimbel, D.A.; Nygaard, H.B.; Gilbert, J.W.; Strittmatter, S.M. Cellular prion protein mediates impairment of synaptic plasticity by amyloid-beta oligomers. Nature 2009, 457, 1128-1132. [CrossRef] [PubMed]

27. Biasini, E.; Harris, D.A. Targeting the cellular prion protein to treat neurodegeneration. Future Med. Chem. 2012, 4, 1655-1658. [CrossRef] [PubMed]

28. Biasini, E.; Turnbaugh, J.A.; Unterberger, U.; Harris, D.A. Prion protein at the crossroads of physiology and disease. Trends Neurosci. 2012, 35, 92-103. [CrossRef] [PubMed]

29. Ferreira, D.G.; Temido-Ferreira, M.; Miranda, H.V.; Batalha, V.L.; Coelho, J.E.; Szego, E.M.; Marques-Morgado, I.; Vaz, S.H.; Rhee, J.S.; Schmitz, M.; et al. Alpha-synuclein interacts with $\operatorname{PrP}^{(\mathrm{c})}$ to induce cognitive impairment through mGluR5 and NMDAR2B. Nat. Neurosci. 2017, 20, 1569-1579. [CrossRef] [PubMed]

30. Minikel, E.V.; Vallabh, S.M.; Lek, M.; Estrada, K.; Samocha, K.E.; Sathirapongsasuti, J.F.; McLean, C.Y.; Tung, J.Y.; Yu, L.P.; Gambetti, P.; et al. Quantifying prion disease penetrance using large population control cohorts. Sci. Transl. Med. 2016, 20, 322-323. [CrossRef] [PubMed]

31. Doh-Ura, K.; Iwaki, T.; Caughey, B. Lysosomotropic agents and cysteine protease inhibitors inhibit scrapie-associated prion protein accumulation. J. Virol. 2000, 74, 4894-4897. [CrossRef] [PubMed]

32. Korth, C.; May, B.C.; Cohen, F.E.; Prusiner, S.B. Acridine and phenothiazine derivatives as pharmacotherapeutics for prion disease. Proc. Natl. Acad. Sci. USA 2001, 98, 9836-9841. [CrossRef] [PubMed]

33. Ryou, C.; Legname, G.; Peretz, D.; Craig, J.C.; Baldwin, M.A.; Prusiner, S.B. Differential inhibition of prion propagation by enantiomers of quinacrine. Lab. Investig. 2003, 83, 837-843. [CrossRef] [PubMed]

34. Collins, S.J.; Lewis, V.; Brazier, M.; Hill, A.F.; Fletcher, A.; Masters, C.L. Quinacrine does not prolong survival in a murine Creutzfeldt-JaKob disease model. Ann. Neurol. 2002, 52, 503-506. [CrossRef] [PubMed]

35. Barret, A.; Tagliavini, F.; Forloni, G.; Bate, C.; Salmona, M.; Colombo, L.; De Luigi, A.; Limido, L.; Suardi, S.; Rossi, G.; et al. Evaluation of quinacrine treatment for prion diseases. J. Virol. 2003, 77, 8462-8469. [CrossRef] [PubMed]

36. Collinge, J.; Gorham, M.; Hudson, F.; Kennedy, A.; Keogh, G.; Pal, S.; Rossor, M.; Rudge, P.; Siddique, D.; Spyer, M.; et al. Safety and efficacy of quinacrine in human prion disease (prion-1 study): A patientpreference trial. Lancet Neurol. 2009, 8, 334-344. [CrossRef]

37. Geschwind, M.D.; Kuo, A.L.; Wong, K.S.; Haman, A.; Devereux, G.; Raudabaugh, B.J.; Johnson, D.Y.; Torres-Chae, C.C.; Finley, R.; Garcia, P.; et al. Quinacrine treatment trial for sporadic Creutzfeldt-JaKob disease. Neurology 2013, 81, 2015-2023. [CrossRef] [PubMed]

38. Ahn, M.; Ghaemmaghami, S.; Huang, Y.; Phuan, P.W.; May, B.C.; Giles, K.; DeArmond, S.J.; Prusiner, S.B. Pharmacokinetics of quinacrine efflux from mouse brain via the P-glycoprotein efflux transporter. PLOS ONE 2012, 7, e39112. [CrossRef] [PubMed]

39. Vogtherr, M.; Grimme, S.; Elshorst, B.; Jacobs, D.M.; Fiebig, K.; Griesinger, C.; Zahn, R. Antimalarial drug quinacrine binds to C-terminal helix of cellular prion protein. J. Med. Chem. 2003, 46, 3563-3564. [CrossRef] [PubMed]

40. Kawatake, S.; Nishimura, Y.; Sakaguchi, S.; Iwaki, T.; Doh-ura, K. Surface plasmon resonance analysis for the screening of anti-prion compounds. Biol. Pharm. Bull. 2006, 29, 927-932. [CrossRef] [PubMed]

41. Touil, F.; Pratt, S.; Mutter, R.; Chen, B. Screening a library of potential prion therapeutics against cellular prion proteins and insights into their mode of biological activities by surface plasmon resonance. J. Pharm. Biomed. Anal. 2006, 40, 822-832. [CrossRef] [PubMed]

42. Georgieva, D.; Schwark, D.; von Bergen, M.; Redecke, L.; Genov, N.; Betzel, C. Interactions of recombinant prions with compounds of therapeutical significance. Biochem. Biophys. Res. Commun. 2006, 344, 463-470. [CrossRef] [PubMed]

43. Cope, H.; Mutter, R.; Heal, W.; Pascoe, C.; Brown, P.; Pratt, S.; Chen, B. Synthesis and SAR study of acridine, 2-methylquinoline and 2-phenylquinazoline analogues as anti-prion agents. Eur. J. Med. Chem. 2006, 41, 1124-1143. [CrossRef] [PubMed]

44. Huang, Y.; Okochi, H.; May, B.C.; Legname, G.; Prusiner, S.B.; Benet, L.Z.; Guglielmo, B.J.; Lin, E.T. Quinacrine is mainly metabolized to mono-desethyl quinacrine by CYP3A4/5 and its brain accumulation is limited by P-glycoprotein. Drug Metab. Dispos. 2006, 34, 1136-1144. [CrossRef] [PubMed] 
45. Nguyen, T.; Sakasegawa, Y.; Doh-Ura, K.; Go, M.L. Anti-prion activities and drug-like potential of functionalized quinacrine analogs with basic phenyl residues at the 9-amino position. Eur. J. Med. Chem. 2011, 46, 2917-2929. [CrossRef] [PubMed]

46. Nguyen, T.H.; Lee, C.Y.; Teruya, K.; Ong, W.Y.; Doh-ura, K.; Go, M.L. Antiprion activity of functionalized 9-aminoacridines related to quinacrine. Bioorg. Med. Chem. 2008, 16, 6737-6746. [CrossRef] [PubMed]

47. Kamatari, Y.O.; Hayano, Y.; Yamaguchi, K.; Hosokawa-Muto, J.; Kuwata, K. Characterizing antiprion compounds based on their binding properties to prion proteins: Implications as medical chaperones. Protein Sci. 2013, 22, 22-34. [CrossRef] [PubMed]

48. Nicoll, A.J.; Trevitt, C.R.; Tattum, M.H.; Risse, E.; Quarterman, E.; Ibarra, A.A.; Wright, C.; Jackson, G.S.; Sessions, R.B.; Farrow, M.; et al. Pharmacological chaperone for the structured domain of human prion protein. Proc. Natl. Acad. Sci. USA 2010, 107, 17610-17615. [CrossRef] [PubMed]

49. Baral, P.K.; Swayampakula, M.; Rout, M.K.; Kav, N.N.; Spyracopoulos, L.; Aguzzi, A.; James, M.N. Structural basis of prion inhibition by phenothiazine compounds. Structure 2014, 22, 291-303. [CrossRef] [PubMed]

50. Stincardini, C.; Massignan, T.; Biggi, S.; Elezgarai, S.R.; Sangiovanni, V.; Vanni, I.; Pancher, M.; Adami, V.; Moreno, J.; Stravalaci, M.; et al. An antipsychotic drug exerts anti-prion effects by altering the localization of the cellular prion protein. PLoS ONE 2017, 12, e0182589. [CrossRef] [PubMed]

51. Daniel, J.A.; Chau, N.; Abdel-Hamid, M.K.; Hu, L.; von Kleist, L.; Whiting, A.; Krishnan, S.; Maamary, P.; Joseph, S.R.; Simpson, F.; et al. Phenothiazine-derived antipsychotic drugs inhibit dynamin and clathrin-mediated endocytosis. Traffic 2015, 16, 635-654. [CrossRef] [PubMed]

52. Yamasaki, T.; Suzuki, A.; Hasebe, R.; Horiuchi, M. Comparison of the anti-prion mechanism of four different anti-prion compounds, anti-PrP monoclonal antibody 44B1, pentosan polysulfate, chlorpromazine, and u18666a, in prion-infected mouse neuroblastoma cells. PLoS ONE 2014, 9, e106516. [CrossRef] [PubMed]

53. Cavaliere, P.; Torrent, J.; Prigent, S.; Granata, V.; Pauwels, K.; Pastore, A.; Rezaei, H.; Zagari, A. Binding of methylene blue to a surface cleft inhibits the oligomerization and fibrillization of prion protein. Biochim. Biophys. Acta 2013, 1832, 20-28. [CrossRef] [PubMed]

54. Mori, T.; Koyama, N.; Segawa, T.; Maeda, M.; Maruyama, N.; Kinoshita, N.; Hou, H.; Tan, J.; Town, T. Methylene blue modulates beta-secretase, reverses cerebral amyloidosis, and improves cognition in transgenic mice. J. Biol. Chem. 2014, 289, 30303-30317. [CrossRef] [PubMed]

55. Sontag, E.M.; Lotz, G.P.; Agrawal, N.; Tran, A.; Aron, R.; Yang, G.; Necula, M.; Lau, A.; Finkbeiner, S.; Glabe, C.; et al. Methylene blue modulates huntingtin aggregation intermediates and is protective in huntington's disease models. J. Neurosci. 2012, 32, 11109-11119. [CrossRef] [PubMed]

56. Wischik, C.M.; Edwards, P.C.; Lai, R.Y.; Roth, M.; Harrington, C.R. Selective inhibition of alzheimer disease-like tau aggregation by phenothiazines. Proc. Natl. Acad. Sci. USA 1996, 93, 11213-11218. [CrossRef] [PubMed]

57. Yamashita, M.; Nonaka, T.; Arai, T.; Kametani, F.; Buchman, V.L.; Ninkina, N.; Bachurin, S.O.; Akiyama, H.; Goedert, M.; Hasegawa, M. Methylene blue and dimebon inhibit aggregation of TDP-43 in cellular models. FEBS Lett. 2009, 583, 2419-2424. [CrossRef] [PubMed]

58. Caughey, W.S.; Raymond, L.D.; Horiuchi, M.; Caughey, B. Inhibition of protease-resistant prion protein formation by porphyrins and phthalocyanines. Proc. Natl. Acad. Sci. USA 1998, 95, 12117-12122. [CrossRef] [PubMed]

59. Priola, S.A.; Raines, A.; Caughey, W.S. Porphyrin and phthalocyanine antiscrapie compounds. Science 2000, 287, 1503-1506. [CrossRef] [PubMed]

60. Massignan, T.; Cimini, S.; Stincardini, C.; Cerovic, M.; Vanni, I.; Elezgarai, S.R.; Moreno, J.; Stravalaci, M.; Negro, A.; Sangiovanni, V.; et al. A cationic tetrapyrrole inhibits toxic activities of the cellular prion protein. Sci. Rep. 2016, 6, 23180. [CrossRef] [PubMed]

61. Kocisko, D.A.; Caughey, W.S.; Race, R.E.; Roper, G.; Caughey, B.; Morrey, J.D. A porphyrin increases survival time of mice after intracerebral prion infection. Antimicrob. Agents Chemother. 2006, 50, 759-761. [CrossRef] [PubMed]

62. Rajora, M.A.; Lou, J.W.H.; Zheng, G. Advancing porphyrin's biomedical utility via supramolecular chemistry. Chem. Soc. Rev. 2017, 46, 6433-6469. [CrossRef] [PubMed]

63. Caspi, S.; Halimi, M.; Yanai, A.; Sasson, S.B.; Taraboulos, A.; Gabizon, R. The anti-prion activity of congo red. Putative mechanism. J. Biol. Chem. 1998, 273, 3484-3489. [CrossRef] [PubMed] 
64. Milhavet, O.; Mange, A.; Casanova, D.; Lehmann, S. Effect of congo red on wild-type and mutated prion proteins in cultured cells. J. Neurochem. 2000, 74, 222-230. [CrossRef] [PubMed]

65. Caughey, B.; Brown, K.; Raymond, G.J.; Katzenstein, G.E.; Thresher, W. Binding of the protease-sensitive form of prp (prion protein) to sulfated glycosaminoglycan and congo red [corrected]. J. Virol. 1994, 68, 2135-2141. [PubMed]

66. Caughey, B.; Ernst, D.; Race, R.E. Congo red inhibition of scrapie agent replication. J. Virol. 1993, 67, 6270-6272. [PubMed]

67. Ingrosso, L.; Ladogana, A.; Pocchiari, M. Congo red prolongs the incubation period in scrapie-infected hamsters. J. Virol. 1995, 69, 506-508. [PubMed]

68. Rudyk, H.; Knaggs, M.H.; Vasiljevic, S.; Hope, J.; Birkett, C.; Gilbert, I.H. Synthesis and evaluation of analogues of congo red as potential compounds against transmissible spongiform encephalopathies. Eur. J. Med. Chem. 2003, 38, 567-579. [CrossRef]

69. Rudyk, H.; Vasiljevic, S.; Hennion, R.M.; Birkett, C.R.; Hope, J.; Gilbert, I.H. Screening congo red and its analogues for their ability to prevent the formation of PrP-res in scrapie-infected cells. J. Gen. Virol. 2000, 81, 1155-1164. [CrossRef] [PubMed]

70. Sellarajah, S.; Lekishvili, T.; Bowring, C.; Thompsett, A.R.; Rudyk, H.; Birkett, C.R.; Brown, D.R.; Gilbert, I.H. Synthesis of analogues of congo red and evaluation of their anti-prion activity. J. Med. Chem. 2004, 47, 5515-5534. [CrossRef] [PubMed]

71. Risse, E.; Nicoll, A.J.; Taylor, W.A.; Wright, D.; Badoni, M.; Yang, X.; Farrow, M.A.; Collinge, J. Identification of a compound that disrupts binding of amyloid-beta to the prion protein using a novel fluorescence-based assay. J. Biol. Chem. 2015, 290, 17020-17028. [CrossRef] [PubMed]

72. Kuwata, K.; Nishida, N.; Matsumoto, T.; Kamatari, Y.O.; Hosokawa-Muto, J.; Kodama, K.; Nakamura, H.K.; Kimura, K.; Kawasaki, M.; Takakura, Y.; et al. Hot spots in prion protein for pathogenic conversion. Proc. Natl. Acad. Sci. USA 2007, 104, 11921-11926. [CrossRef] [PubMed]

73. Kimura, T.; Hosokawa-Muto, J.; Kamatari, Y.O.; Kuwata, K. Synthesis of GN8 derivatives and evaluation of their antiprion activity in TSE-infected cells. Bioorg. Med. Chem. Lett. 2011, 21, 1502-1507. [CrossRef] [PubMed]

74. Perrier, V.; Wallace, A.C.; Kaneko, K.; Safar, J.; Prusiner, S.B.; Cohen, F.E. Mimicking dominant negative inhibition of prion replication through structure-based drug design. Proc. Natl. Acad. Sci. USA 2000, 97, 6073-6078. [CrossRef] [PubMed]

75. Guo, K.; Mutter, R.; Heal, W.; Reddy, T.R.; Cope, H.; Pratt, S.; Thompson, M.J.; Chen, B. Synthesis and evaluation of a focused library of pyridine dicarbonitriles against prion disease. Eur. J. Med. Chem. 2008, 43, 93-106. [CrossRef] [PubMed]

76. Reddy, T.R.; Mutter, R.; Heal, W.; Guo, K.; Gillet, V.J.; Pratt, S.; Chen, B. Library design, synthesis, and screening: Pyridine dicarbonitriles as potential prion disease therapeutics. J. Med. Chem. 2006, 49, 607-615. [CrossRef] [PubMed]

77. Heal, W.; Thompson, M.J.; Mutter, R.; Cope, H.; Louth, J.C.; Chen, B. Library synthesis and screening: 2,4-diphenylthiazoles and 2,4-diphenyloxazoles as potential novel prion disease therapeutics. J. Med. Chem. 2007, 50, 1347-1353. [CrossRef] [PubMed]

78. Thompson, M.J.; Louth, J.C.; Greenwood, G.K.; Sorrell, F.J.; Knight, S.G.; Adams, N.B.; Chen, B. Improved 2,4-diarylthiazole-based antiprion agents: Switching the sense of the amide group at $\mathrm{C} 5$ leads to an increase in potency. ChemMedChem 2010, 5, 1476-1488. [CrossRef] [PubMed]

79. Porat, Y.; Abramowitz, A.; Gazit, E. Inhibition of amyloid fibril formation by polyphenols: Structural similarity and aromatic interactions as a common inhibition mechanism. Chem. Biol. Drug Des. 2006, 67, 27-37. [CrossRef] [PubMed]

80. Rambold, A.S.; Miesbauer, M.; Olschewski, D.; Seidel, R.; Riemer, C.; Smale, L.; Brumm, L.; Levy, M.; Gazit, E.; Oesterhelt, D.; et al. Green tea extracts interfere with the stress-protective activity of PrP and the formation of PrP. J. Neurochem. 2008, 107, 218-229. [CrossRef] [PubMed]

81. Hosokawa-Muto, J.; Kamatari, Y.O.; Nakamura, H.K.; Kuwata, K. Variety of antiprion compounds discovered through an in silico screen based on cellular-form prion protein structure: Correlation between antiprion activity and binding affinity. Antimicrob. Agents Chemother. 2009, 53, 765-771. [CrossRef] [PubMed] 
82. Kimura, T.; Hosokawa-Muto, J.; Asami, K.; Murai, T.; Kuwata, K. Synthesis of 9-substituted 2,3,4,9-tetrahydro-1H-carbazole derivatives and evaluation of their anti-prion activity in tse-infected cells. Eur. J. Med. Chem. 2011, 46, 5675-5679. [CrossRef] [PubMed]

83. Hyeon, J.W.; Choi, J.; Kim, S.Y.; Govindaraj, R.G.; Jam Hwang, K.; Lee, Y.S.; An, S.S.; Lee, M.K.; Joung, J.Y.; No, K.T.; et al. Discovery of novel anti-prion compounds using in silico and in vitro approaches. Sci. Rep. 2015, 5, 14944. [CrossRef] [PubMed]

84. Ma, B.; Yamaguchi, K.; Fukuoka, M.; Kuwata, K. Logical design of anti-prion agents using nagara. Biochem. Biophys. Res. Commun. 2016, 469, 930-935. [CrossRef] [PubMed]

85. Ishibashi, D.; Nakagaki, T.; Ishikawa, T.; Atarashi, R.; Watanabe, K.; Cruz, F.A.; Hamada, T.; Nishida, N. Structure-based drug discovery for prion disease using a novel binding simulation. EBioMedicine 2016, 9 , 238-249. [CrossRef] [PubMed]

(C) 2018 by the authors. Licensee MDPI, Basel, Switzerland. This article is an open access article distributed under the terms and conditions of the Creative Commons Attribution (CC BY) license (http://creativecommons.org/licenses/by/4.0/). 